ment of ankylosing spondylitis and to compare it with phenylbutazone. The need for a safe and efficacious alternative to phenylbutazone becomes clear from a study of the Register of Adverse Reactions (January 1964-October 1971) made available by the Committee on Safety of Medicines for January 1964-October 1971. During this period there were 864 reports of side effects from phenylbutazone of which 227 were fatal (including aplastic anaemia 101 cases, agranulocytosis 25 cases, and thrombocytopenia 11 cases). There were also 71 deaths among 283 reports of adverse reactions with oxyphenbutazone. Fowler (1974), analysing these deaths, showed that while most of the cases of agranulocytosis occur within the first three months $65 \%$ of the more frequent and more serious complication, aplastic anaemia, occur after this time interval. In ankylosing spondylitis long-term therapy for more than three months is almost invariably indicated.

Our results show that there is little difference between flurbiprofen and phenylbutazone according to most subjective and objective criteria. Phenylbutazone was, however, significantly better than flurbiprofen for duration of morning stiffness. This statistical bias may give a false impression; in fact only three of the 35 patients suffered prolonged morning stiffness while receiving flurbiprofen.

Gross alterations in formulation of trial drugs could alter bioavailability (Cromie, 1963). This problem was avoided by the use of a double-blind substitution technique in which both drugs were presented in their usual form, dummy substitutes of the alternative drug being given concurrently.

Only those individuals known to be tolerant to phenylbutazone were admitted to the trial. It is therefore not surprising that there were no serious side effects from this preparation. It is encouraging that only one patient out of the 37 developed side effects with flurbiprofen necessitating withdrawal from the trial. This individual had vertigo, a symptom which cleared within 48 hours of stopping the drug but returned within hours of restarting. He was therefore withdrawn from the trial despite dramatic clinical improvement with the drug.

Paracetamol as a rescue drug was little used, no doubt because patients with ankylosing spondylitis had, on the whole, become accustomed to their chronic pain and in any case found great benefit from the enforced drug therapy dictated by the trial. Furthermore, many patients who claimed to be symptom free at the start of the trial made a great improvement within days of beginning either preparation (two patients played their first round of golf for years). It seems that many individuals with chronic disability fail to take their medication, not realizing how unwell they are. Many patients with ankylosing spondylitis for this reason are lost to follow up and rheumatology clinics should take every opportunity to prevent this happening.

In conclusion, we have shown that flurbiprofen is effective in ankylosing spondylitis, remarkably free from side effects, and likely to have an important part to play in the management of this chronic disorder.

\section{References}

Adams, S. S., and McCullough, K. F. (1970). In European League against Rheumatism 7th European Rheumatology Congress, Abstract no. 322. London, Arthritis and Rheumatism Council

Bennett, P. H., and Wood, P. N. H. (editors) (1968). Population Studies of the Rheumatic Diseases, p. 456. Amsterdam, Excerpta Medica.

Calin, A., et al. (1974). Lancet, 1, 874.

Chalmers, I. M., et al. (1972). Annals of the Rheumatic Diseases, 31, 319.

Cromie, B. W. (1963). Lancet, 2, 994.

Fowler, P. D. (1974). Personal communication.

Girdwood, R. H. (1974). British Medical fournal, 1, 501.

Masumoto, S., and Takase, K. (1973). In Abstracts of the XIII World Rheumatology Congress, Kyoto.

Moll, J. M. H., and Wright, V. (1971). Annals of the Rheumatic Diseases, 30, 381.

Register of Adverse Reactions (January 1964-October 1971). Vol. I, p. 131. Committee on Safety of Medicines. (Unpublished.)

Steinbrocker, O., Treager, C., and Batterman, R. C. (1949). Fournal of the American Medical Association, 140, 659.

Sturrock, R. D., and Hart, F. P. (1974). Annals of the Rheumatic Diseases, 33, 129.

\title{
Abnormal Drug Metabolism after Barbiturate and Paracetamol Overdose
}

\author{
JOHN A. H. FORREST, P. ROSCOE, L. F. PRESCOTT, I. H. STEVENSON
}

British Medical fournal, 1974, 4, 499-502

\section{Summary}

Drug-metabolizing capacity has been assessed by serial measurements of the plasma antipyrine half life in 11 patients with severe barbiturate intoxication and in 17 patients with acute hepatic necrosis due to paracetamol overdosage. Drug metabolism was strikingly enhanced after barbiturate overdosage, and this effect was still present six weeks later. In contrast the antipyrine half life was greatly prolonged in

Regional Poisoning Treatment Centre and Department of Therapeutics, Royal Infirmary, Edinburgh EH3 9YW

JOHN A. H. FORREST, M.B., M.R.C.P., Registrar

P. ROSCOE, M.B., M.R.C.P., Registrar

L. F. PRESCOTT, M.D., F.R.C.P., Reader and Consultant Physician

Department of Pharmacology and Therapeutics, University of Dundee, Dundee DD1 4HN

I. H. STEVENSON, B.SC., PH.D., Senior Lecturer patients with paracetamol-induced acute hepatic necrosis but returned to normal or near-normal values within seven to 21 days.

\section{Introduction}

Long-term administration of hypnotics such as barbiturates, glutethimide, and diphenhydramine-methaqualone (Mandrax) can cause stimulation of hepatic microsomal enzyme activity and thereby enhance the rate of metabolism of many drugs (MacDonald et al., 1969; Stevenson et al., 1972; Breckenridge et al., 1973 a). This stimulatory effect develops over three to four weeks and persists for a similar period after the inducing drug is discontinued. The barbiturates produce a dose-related induction of microsomal enzymes in man (Breckenridge et al., 1973 a), and marked acceleration of drug metabolism might be expected after severe overdosage with these drugs since this probably represents the maximum stimulus for induction likely to be encountered in practice. On the other hand, drug metabolism is likely to 
be seriously impaired in patients with acute hepatic injury, such as that caused by paracetamol overdosage (Prescott and Stevenson, 1973; Simpson and Stewart, 1973). It is clearly important to establish the effects of overdosage on drug metabolism so that any drugs required subsequently can be given in appropriate dosage.

In this report we describe studies of drug metabolism in patients after severe barbiturate and paracetamol poisoning. The plasma antipyrine half life was used as an index of hepatic drug metabolism and studies were carried out at intervals after overdosage to establish the time course of the changes produced.

\section{Patients and Methods}

\section{BARBITURATE OVERDOSAGE}

Studies were carried out on 11 patients admitted to the Regional Poisoning Treatment Centre because of intoxication with short-acting or medium-acting barbiturates. Nine patients were in grade IV coma and two (cases 7 and 8) were in grade III coma (Matthew and Lawson, 1970). The ingestion of other drugs commonly taken in overdosage was excluded by a urine screening technique but one patient (case 10) had also taken alcohol (blood alcohol on admission 173 $\mathrm{mg} / 100 \mathrm{ml}$ ). The clinical details are summarized in table 1 . None of the patients had a history of previous liver disease or chronic alcoholism and there was no clinical evidence of cardiac or renal disease. Two patients (cases 1 and 5) were addicted to barbiturates, four (cases 2, 9, 10, and 11) took them regularly as a hypnotic, and one (case 11) had also taken prednisolone 5-10 mg daily for some years because of asthma.

Treatment consisted in routine intensive supportive therapy with gastric lavage when indicated (Matthew and Lawson, 1970). Intermittent positive-pressure ventilation was used in cases $1,2,3,4,10$, and 11 for a mean period of $31 \cdot 2$ hours. All patients recovered without complications.

The plasma antipyrine half life was measured on the first morning that the patient was conscious and able to take fluids (study 1). The mean interval between admission and study 1 was 51.2 hours (range $20-87$ hours). In eight patients the antipyrine half life was measured again a week later (study 2) and in five the test was repeated after another five weeks (study 3). The patients remained in hospital between studies 1 and 2 and did not receive any drugs other than ampicillin.

Plasma barbiturate concentrations were usually estimated at intervals of six to eight hours from admission until the completion of study 1 . The drugs were extracted into chloroform and estimated by direct gas-liquid chromatography on SE 52 columns (Street, 1969).

\section{PARACETAMOL OVERDOSAGE}

The plasma antipyrine half life was measured in 17 patients with acute hepatic necrosis after paracetamol overdosage (see table II). Apart from one patient (case 20), who was a chronic alcoholic, none was known to have pre-existing liver disease. An epileptic patient (case 15) was taking phenobarbitone, and three others (cases 13, 23, and 26) claimed to have been taking fluphenazine with orphenadrine, Minovlar (norethisterone), and nitrazepam respectively before admission. Four patients had taken alcohol at the time of overdosage. Apart from two patients (cases 13 and 23) who received fresh frozen plasma no treatment was required. The severity of the hepatic necrosis was assessed by daily measurement of the prothrombin time, serum alanine aminotransferase (SGPT) activity, and bilirubin concentration. Plasma paracetamol concentrations were determined on admission in 15 cases, and in 14 cases blood samples were taken at intervals for up to 36

TABLE I-Barbiturate Overdosage. Clinical and Laboratory Details

\begin{tabular}{|c|c|c|c|c|c|c|c|c|}
\hline \multirow[b]{2}{*}{$\begin{array}{l}\text { Case } \\
\text { No. }\end{array}$} & \multirow[b]{2}{*}{$\begin{array}{c}\text { Age } \\
\text { (Years) }\end{array}$} & \multirow[b]{2}{*}{ Sex } & \multirow{2}{*}{ Barbiturate } & \multirow{2}{*}{$\begin{array}{c}\underset{\text { Maximum }}{\text { Plasma }} \\
\text { Concentration } \\
(\mu \mathrm{g} / \mathrm{ml})\end{array}$} & \multirow{2}{*}{$\begin{array}{c}\text { Total } \\
\text { Duration } \\
\text { of Coma } \\
\text { (Hours) } \\
\end{array}$} & \multicolumn{3}{|c|}{ Antipyrine Half Life (Hours) } \\
\hline & & & & & & Study 1 & Study 2 & Study 3 \\
\hline $\begin{array}{rr}1 & \\
2 & \\
3 & \\
4 & \\
5 \dagger & \\
6 & \\
7 & \\
8 & \\
9 & \\
10 & \\
11 & \\
\end{array}$ & $\begin{array}{l}49 \\
52 \\
24 \\
67 \\
44 \\
44 \\
29 \\
26 \\
22 \\
69 \\
43 \\
41\end{array}$ & $\begin{array}{l}\text { F. } \\
\text { F. } \\
\text { F. } \\
\text { M. } \\
\text { M. } \\
\text { M. } \\
\text { M. } \\
\text { F. } \\
\text { F. } \\
\text { F. }\end{array}$ & $\begin{array}{l}\text { Cyclobarbitone } \\
\text { Amylobarbitone } \\
\text { Amylobarbitone, quinalbarbitone* } \\
\text { Amylobarbitone } \\
\text { Butobarbitone } \\
\text { Butobarbitone } \\
\text { Amylobarbitone, quinalbarbitone* } \\
\text { Pentobarbitone } \\
\text { Amylobarbitone, quinalbarbitone* } \\
\text { Pentobarbitone } \\
\text { Quinalbarbitone } \\
\text { Amylobarbitone, quinalbarbitone* } \\
\end{array}$ & $\begin{array}{r}142 \\
66 \\
76,52 \\
40 \\
118 \\
100 \\
17,15 \\
27 \\
16,13 \\
26 \\
67 \\
34,32 \\
\end{array}$ & $\begin{array}{l}30 \\
59 \\
80 \\
44 \\
18 \\
30 \\
48 \\
27 \\
33 \\
43 \\
44 \\
57\end{array}$ & $\begin{array}{l}6 \cdot 95 \\
5 \cdot 3 \\
8 \cdot 0 \\
7 \cdot 6 \\
7 \cdot 0 \\
4 \cdot 9 \\
5 \cdot 1 \\
8 \cdot 6 \\
4 \cdot 8 \\
3 \cdot 4 \\
4 \cdot 8 \\
5 \cdot 7 \\
\end{array}$ & $\begin{array}{l}4.9 \\
3.5 \\
7.4 \\
3.7 \\
3.3 \\
3.9 \\
6.5 \\
5.4\end{array}$ & $\begin{array}{r}6 \cdot 3 \\
10 \cdot 2 \\
5.6\end{array}$ \\
\hline Mean \pm S.E. & $42 \cdot 4 \pm 4 \cdot 9$ & & & $70 \cdot 1 \pm 11 \cdot 4$ & $42 \cdot 8 \pm 4 \cdot 9$ & $6.0 \pm 0.5$ & $4.8 \pm 0.5$ & $7 \cdot 7 \pm 0.8$ \\
\hline
\end{tabular}

*Tuinal. †This patient took butobarbitone in overdosage on two occasions.

TABLE II-Paracetamol Overdosage. Clinical and Laboratory Details

\begin{tabular}{|c|c|c|c|c|c|c|c|c|c|c|c|}
\hline \multirow[b]{2}{*}{$\begin{array}{l}\text { Case } \\
\text { No. }\end{array}$} & \multirow[b]{2}{*}{$\begin{array}{l}\text { Age } \\
\text { (Years) }\end{array}$} & \multirow[b]{2}{*}{ Sex } & \multirow[b]{2}{*}{$\begin{array}{c}\text { Paracetamol } \\
\text { Half Life } \\
\text { (Hours) }\end{array}$} & \multirow[b]{2}{*}{$\underset{\text { SGPT }}{\text { Maximum }}$} & \multirow[b]{2}{*}{$\underset{\text { Bilirubin }}{\text { Maximum }}$} & \multirow[b]{2}{*}{$\begin{array}{c}\text { Maximum } \\
\text { Prothrombin } \\
\text { (Ratio) }\end{array}$} & \multirow{2}{*}{$\begin{array}{c}\text { Interval between } \\
\text { Admission and } \\
\text { Initial } \\
\text { Antipyrine Study } \\
\text { (Days) }\end{array}$} & \multicolumn{2}{|c|}{ Initial Study } & \multicolumn{2}{|c|}{ Follow-up Study } \\
\hline & & & & & & & & $\begin{array}{c}\text { Antipyrine } \\
\text { Half Life } \\
\text { (Hours) } \\
\end{array}$ & $\begin{array}{c}\text { SGPT on } \\
\text { Same Day } \\
\text { (IU/l) }\end{array}$ & $\begin{array}{c}\text { Antipyrine } \\
\text { Half Life } \\
\text { (Hours) }\end{array}$ & $\begin{array}{l}\text { SGPT on } \\
\text { Same Day } \\
\text { (IU/l) }\end{array}$ \\
\hline $\begin{array}{l}12 \\
13 \\
14 \\
15 \\
16 \\
17 \\
18 \\
19 \\
20 \\
21 \\
22 \\
23 \\
24 \\
25 \\
26 \\
27 \\
28\end{array}$ & $\begin{array}{l}18 \\
25 \\
29 \\
38 \\
49 \\
20 \\
21 \\
22 \\
43 \\
22 \\
40 \\
19 \\
26 \\
29 \\
18 \\
22 \\
20 \\
\end{array}$ & $\begin{array}{l}\text { F. } \\
\text { M. } \\
\text { M. } \\
\text { F. } \\
\text { F. } \\
\text { M. } \\
\text { F. } \\
\text { M. } \\
\text { M. } \\
\text { F. } \\
\text { F. } \\
\text { F. } \\
\text { M. } \\
\text { F. } \\
\text { F. } \\
\text { F. } \\
\text { M. }\end{array}$ & $\begin{array}{l}3.1 \\
9.7 \\
5 \cdot 8 \\
8.6 \\
5.5 \\
5 \cdot 3 \\
5.8 \\
4.5 \\
7 \cdot 6 \\
4 \cdot 6 \\
5.8 \\
3.8 \\
6.8 \\
4.1 \\
\end{array}$ & $\begin{array}{r}274 \\
9600 \\
2760 \\
7500 \\
>2000 \\
1800 \\
222 \\
2820 \\
3200 \\
756 \\
684 \\
4020 \\
411 \\
5360 \\
168 \\
3200 \\
52\end{array}$ & $\begin{array}{l}0.6 \\
7.0 \\
1.3 \\
5.7 \\
4.3 \\
0.8 \\
1.5 \\
2.6 \\
2.0 \\
1.0 \\
5.5 \\
1.4 \\
1.2 \\
0.8 \\
1.1 \\
0.9\end{array}$ & $\begin{array}{l}1.3 \\
3.2 \\
2.9 \\
2.0 \\
1.5 \\
1.2 \\
1.7 \\
1.2 \\
1.3 \\
1.3 \\
2.4 \\
1.4 \\
1.8 \\
1.2 \\
1.2 \\
1.4\end{array}$ & $\begin{array}{l}1.5 \\
5.0 \\
2.0 \\
7.0 \\
4.5 \\
7.0 \\
1.5 \\
2.5 \\
1.5 \\
3.5 \\
1.5 \\
3.5 \\
1.5 \\
2.0 \\
2.0 \\
6.0 \\
2.0\end{array}$ & $\begin{array}{l}14 \cdot 0 \\
25 \cdot 4 \\
30 \cdot 6 \\
8 \cdot 8 \\
27 \cdot 5 \\
16 \cdot 5 \\
15 \cdot 3 \\
28 \cdot 8 \\
17 \cdot 3 \\
27 \cdot 3 \\
22 \cdot 8 \\
32 \cdot 7 \\
15 \cdot 6 \\
20 \cdot 4 \\
12 \cdot 6 \\
22 \cdot 6 \\
12 \cdot 1\end{array}$ & $\begin{array}{r}128 \\
>2000 \\
648 \\
1152 \\
>2000 \\
1800 \\
97 \\
1340 \\
253 \\
756 \\
183 \\
2780 \\
411 \\
504 \\
129 \\
912 \\
52\end{array}$ & $\begin{array}{r}14.2 \\
16.5 \\
\\
14.5 \\
9.3 \\
9.6 \\
12.3 \\
16.6\end{array}$ & $\begin{array}{r}588 \\
27 \\
\\
672 \\
156 \\
684 \\
33 \\
25\end{array}$ \\
\hline $\begin{array}{c}\text { Mean } \pm \\
\text { S.E. }\end{array}$ & $27 \cdot 1 \pm 2 \cdot 3$ & & $5.8 \pm 0.5$ & $2639 \pm 664$ & $2.3 \pm 0.5$ & $1 \cdot 7 \pm 0 \cdot 2$ & $3.2 \pm 0.5$ & $20 \cdot 6 \pm 1 \cdot 8$ & $891 \pm 201$ & $13 \cdot 3 \pm 1 \cdot 0$ & $280 \pm 109$ \\
\hline
\end{tabular}


hours for estimation of the plasma paracetamol half life. Paracetamol was estimated using a gas-liquid chromatographic method (Prescott, 1971).

In patients with mild to moderate liver damage the antipyrine half life was usually measured within two days of admission, but in patients with severe hepatic necrosis administration of antipyrine was delayed until there was clinical or biochemical evidence of recovery (table II). The antipyrine half life was determined again in eight patients who could be followed up. In five patients the second study was carried out seven days after the first, and in the remaining three the intervals were 21 days (cases 13 and 27) and 63 days (case 20). The plasma antipyrine was measured as described by O'Malley et al. (1971), though in some patients with liver damage additional blood samples were taken for up to 24 hours. The statistical significance of changes in antipyrine half life and volumes of distribution was assessed using Student's $t$ test.

\section{Results}

\section{BARBITURATE OVERDOSAGE}

The mean maximum plasma barbiturate concentration was $70.1 \mu \mathrm{g} / \mathrm{ml}$ and the men duration of unconsciousness was 42.8 hours (table I). On the day that the patients regained consciousness (study 1 ) the mean ( \pm S.E.) antipyrine half life was only $6.0 \pm 0.5$ hours compared with $12.0 \pm 0.5$ hours previously observed in healthy adults aged 20 to 50 years (O'Malley et al., 1971). One week later (study 2) the antipyrine half life had shortened to $4.8 \pm 0.5$ hours, the lowest individual value being 3.3 hours. Six weeks after the overdosage (study 3 ) the mean antipyrine half life had increased but was still abnormally short at $7.7 \pm 0.8$ hours (fig. 1). The mean antipyrine half life in all three studies differed significantly from normal and from each other $(P<0.005)$. There were no significant differences between the apparent mean volumes of antipyrine distribution in the three studies $(0.63,0.60$, and $0.631 . / \mathrm{kg}$ respectively).

There was a progressive increase in the rate of elimination of barbiturates from the plasma during recovery in nine patients; these findings are also in keeping with stimulation of hepatic microsomal enzymes during the recovery phase. An example is shown in fig. 2 . The mean plasma barbiturate half life in the whole group during the first 24 hours after admission was $25.1 \pm 3.5$ hours but this had fallen to $10.7 \pm$ 0.8 hours on the day that the first antipyrine study was carried out. At that time there was no statistically significant correlation between the barbiturate and antipyrine half lives $(\mathrm{r}=0.37 ; \mathrm{P}>0.2)$.

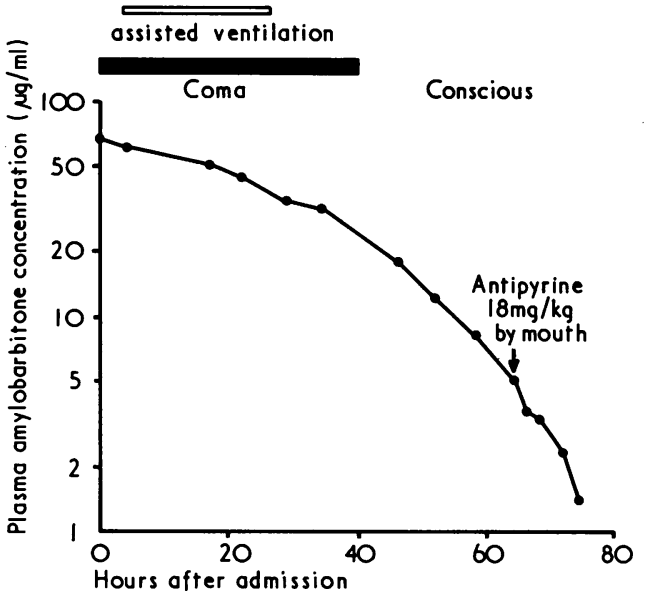

FIG. 2-Increasing rate of disappearance of amylobarbitone from plasma in case 2 during recovery from amylobarbitone intoxication.

\section{PARACETAMOL OVERDOSAGE}

The mean interval between ingestion of paracetamol and admission was $8.6 \pm 1.5$ hours, the mean plasma paracetamol concentration on admission being $189 \pm 24 \mu \mathrm{g} / \mathrm{ml}$. The paracetamol half life was more than four hours in 12 of the 14 patients in whom it was estimated (Prescott et al., 1971). SPGT activity exceeded the upper limit of normal (35 IU/1.) in all 17 cases, the mean maximum value being 2,639 IU/1. (table II). At the time of the initial and follow-up antipyrine studies the mean SPGT levels were 891 and $280 \mathrm{IU} / 1$. respectively.

The mean plasma antipyrine half life in the initial study was 20.6 hours (fig. 1) and there were highly significant correlations between the antipyrine half life and the SGPT activity on the same day ( $\mathrm{r}=0.92$ ) (fig. 3) and the plasma paracetamol half life $(r=0.72)$. Similar but less striking correlations were observed between the antipyrine half life and the serum bilirubin $(r=0.52)$ and prothrombin time ratio $(r=0.53)$ determined on the day of the antipyrine test. In only one patient (case 15) was the antipyrine half life shorter than normal ( 8.8 hours), but this patient was on long-term phenobarbitone therapy.

When the antipyrine study was repeated in eight patients after an interval of seven to 63 days the mean half life had fallen to 13.3 hours (fig. 1). On this occasion there was no sig-

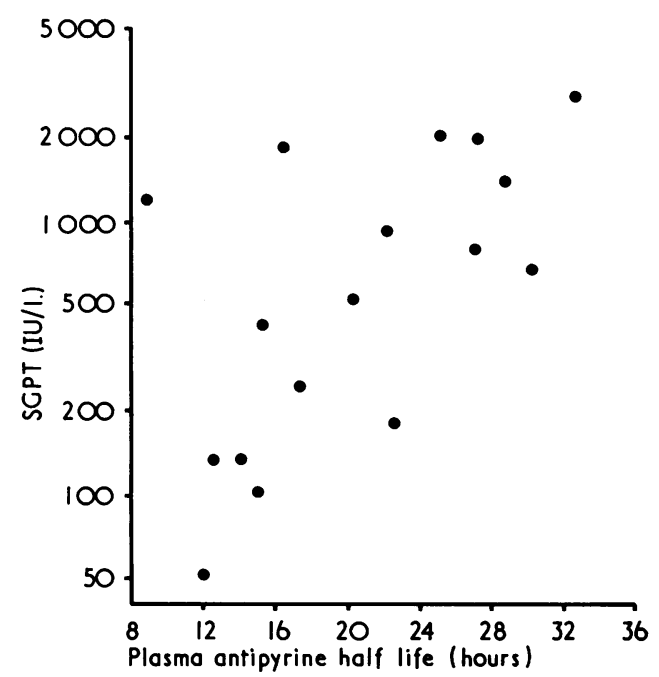

FIG. 3-Correlation between plasma antipyrine half life and SGPT measured on same day in patients with paracetamol-induced hepatic necrosis $(r=0.92)$.
FIG. 1-Mean plasma antipyrine half life in normal subjects and in patients after barbiturate and paracetamol overdosage.

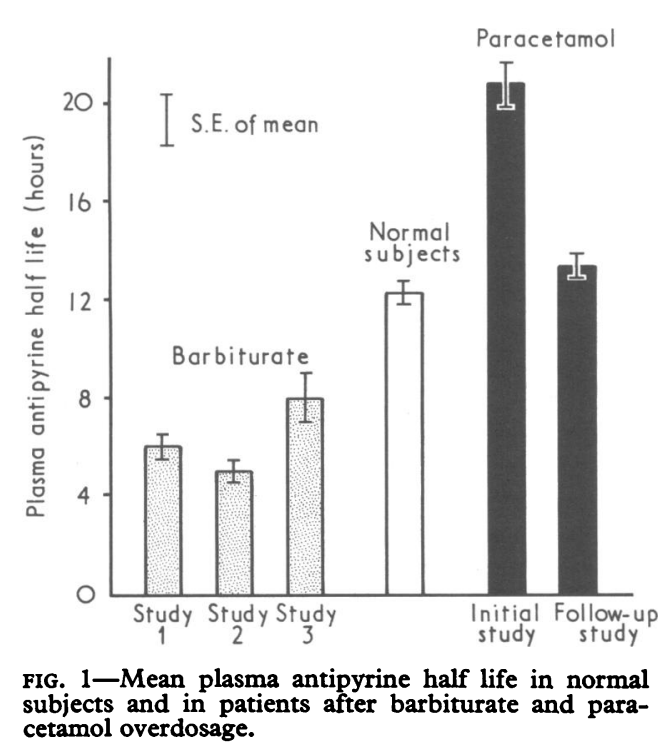


nificant correlation with SGPT activity, and in three patients with SGPT values ranging from 588 to $684 \mathrm{IU} / 1$. the antipyrine half life ranged from 9.6 to 14.5 hours (table II). The mean volumes of antipyrine distribution at the initial and follow-up studies were 0.54 and $0.621 . / \mathrm{kg}$. A paired $t$ test carried out on the data from the eight patients studied twice showed no statistically significant difference $(t=1.04 ; \mathrm{P}>$ 0.05).

\section{Discussion}

The plasma antipyrine half life is widely used as a measure of drug-metabolizing capacity in man, and several investigators have observed changes after treatment with drugs which cause induction or inhibition of microsomal drugmetabolizing enzymes (Kolmodin et al., 1969; Vessell and Page, 1969; Kampffmeyer, 1971; O'Malley et al., 1972). Though the rate of elimination of antipyrine does not always correlate with the plasma half life of other drugs metabolized by the liver microsomal enzymes (Kadar et al., 1973) there seems little doubt that in the present study drug metabolism was enhanced after severe barbiturate intoxication and impaired in patients with acute hepatic necrosis due to paracetamol overdosage. Though previous work (Remmer, 1962) suggested that barbiturate poisoning may stimulate hepatic drug metabolism no detailed assessment of this finding seems to have been carried out.

Significant enzyme induction had probably occurred by the time our barbiturate patients regained consciousness, since both the barbiturate and antipyrine half lives were abnormally short at that time. For example, the plasma half life of amylobarbitone in healthy adults is about 24 hours (Balasubramaniam et al., 1970) but in some of our patients it had fallen to six to 12 hours on recovery. Progressive shortening of the plasma barbiturate half life during recovery from severe intoxication does not seem to have been described previously. Though this was probably due largely to enzyme induction the initial rate of disappearance of barbiturate from the plasma could have been slowed by factors such as continuing gastrointestinal absorption, hypothermia, hypotension, hypoxia, and, perhaps, dose-dependent metabolism. In addition the metabolism of barbiturate may have been enhanced by increased production of cortisol during recovery (Collins et al., 1971) since the elimination of antipyrine in normal subjects can be increased by infusion of physiological doses of hydrocortisone (Breckenridge et al., 1973 b).

The plasma antipyrine half life was even shorter seven days after the patients regained consciousness and the metabolism of the drug was still abnormally rapid six weeks after the overdosage. Thus for at least six weeks after severe barbiturate poisoning drugs which are primarily inactivated by hepatic microsomal enzymes may have to be given more often and in increased dosage in order to produce the desired therapeutic effects.
In contrast the metabolism of antipyrine was impaired in the patients with paracetamol-induced acute hepatic necrosis. Prolongation of the antipyrine half life was related to the extent of liver damage as shown by the paracetamol half life, SGPT activity, serum bilirubin, and the prothrombin time ratio. The only patient with an antipyrine half life of less than 12 hours was an epileptic in whom previous consumption of phenobarbitone had presumably caused microsomal enzyme induction. The antipyrine half life in patients receiving anticonvulsants may be reduced to four to five hours (I. H. Stevenson, unpublished).

Drug metabolism apparently returned to normal within seven to 21 days of severe paracetamol overdosage though the SGPT activity was still raised in some patients. Thus during this period it is possible that other drugs might have to be given in reduced dosage to prevent cumulation and toxicity. Combined overdosage of paracetamol and hypnotics is particularly dangerous, and prolonged coma due to impairment of barbiturate metabolism has been observed in patients taking a combination of barbiturates and paracetamol in overdosage (Prescott and Stevenson, 1973; Simpson and Stewart, 1973).

We are indebted to Dr. Henry Matthew for encouragement and advice. Our thanks are also due to the nursing staff of the Regional Poisoning Treatment Centre. We gratefully acknowledge the expert technical help provided by Mrs. M. E. Roberts, Mrs. S. Mann, and Mrs. M. West. This study was supported by a grant from the Scottish Hospitals Endowment Research Trust.

\section{References}

Balasubramaniam, K., et al. (1970). British fournal of Pharmacology, 39, 564. Breckenridge, A., et al. (1973 a). Clinical Pharmacology and Therapeutics, 14, 514.

Breckenridge, A., et al. (1973 b). British fournal of Pharmacology, 47, 434. Collins, J. V., et al. (1971). Lancet, 2, 184.

Kadar, D., et al. (1973). Clinical Pharmacology and Therapeutics, 14, 552.

Kampffmeyer, H. G. (1971). European fournal of Clinical Pharmacology, 3, 113.

Kolmodin, B., Azarnoff, D. L., and Sjoqvist, F. (1969). Clinical Pharmacology and Therapeutics, 10,638 .

MacDonald, M. G., et al. (1969). Clinical Pharmacology and Therapeutics, 10,80 .

Matthew, H., and Lawson, A. A. H. (1970). In Treatment of Common Acute Poisonings, 2nd edn. Edinburgh, Churchill Livingstone.

O'Malley, K., et al. (1971). British Medical fournal, 3, 607 .

O'Malley, K., Stevenson, I. H., and Crooks, J. (1972). Clinical Pharmacology and Therapeutics, 13,552 .

Prescott, L. F. (1971). Fournal of Pharmacy and Pharmacology, 23, 807.

Prescott, L. F., and Stevenson, I. H. (1973). In Proceedings of 5th International Congress on Pharmacology, ed. by G. H. Acheson, vol. 3, p. 182. Basel, Karger.

Prescott, L. F., et al. (1971). Lancet, 1, 519.

Remmer, H. (1962). Enzymes and Drug Action, Ciba Foundation Symposium ed. J. L. Mongar and A. V. S. de Renck, p. 276. London, Churchill.

Simpson, E., and Stewart, M. J. (1973). Annals of Clinical Biochemistry, 10,171 .

Stevenson, I. H., et al. (1972). British Meedical fournal, 4, 322.

Street, H. V. (1969). Advances in Clinical Chemistry, 12, 217.

Vessell, E. S., and Page, J. G. (1969). Fournal of Clinical Investigation, 48, 2202 . 